\title{
Progress in Indium Phosphide Solar Cell Research
}

\author{
I. Weinberg, C. K. Swartz and R. E. Hart, Jr. \\ NASA Lewis Research Center \\ Cleveland, $O H \$ 4195$
}

\begin{abstract}
Progress, dating from the start of the Lewis program, is reviewed emphasizing processing techniques which have achieved the highest efficiencies in a given year. To date, the most significant achievement has been attainment of AM0 total area efficiencies approaching $19 \%$. Although closed tube diffusion is not considered to be an optimum process, reasonably efficient $2 \mathrm{~cm} \times 2 \mathrm{~cm}$ and $1 \mathrm{~cm}$ $\times 2 \mathrm{~cm} \mathrm{InP}$ cells have been produced in quantity by this method with a satellite to be launched in 1990 using these cells. Proton irradiation of these relatively large area cells indicates radiation resistance comparable to that previously reported for smaller InP cells. A similar result is found for the initial proton irradiations of ITO/InP cells processed by D. C. sputtering. With respect to computer modelling, a comparison of $\mathrm{n} / \mathrm{p}$ homojunction $\mathrm{In} \mathrm{P}$ and $\mathrm{GaAs}$ cels of identical geometries and dopant concentrations has confirmed the superior radiation resistance of InP cells under $1 \mathrm{MeV}$ electron irradiations.
\end{abstract}

\section{Introduction}

Indium Phosphide solar cells are excellent candidates for use in the space radiation environment. This follows from their significantly increased radiation resistance when compared to gallium arsenide and silicon [ref. 1]. In addition, InP cells have been observed to anneal at room temperature under dark conditions and under the influence of incident light [refs. 2,3]. Furthermore, AM0 total area efficiencies of over $20 \%$ have been predicted using a conservative model [ref. 4]. For these reasons,the NASA Lewis Research Center has been conducting a program aimed at developing high efficiency, radiation resistant InP solar cells. The current paper reviews progress, during the past year, in both the U.S. and Japan. It is noted that a summary of the results presented at this conference would, in itself, constitute a progress review. However, to avoid unnecessary duplication, the present review deals mainly with results which are in addition to the remaining InP papers presented at this conference.

\section{Cell Performance}

Interest in InP solar cells was stimulated by the demonstration, in 1984, that relatively high efficiency $\mathrm{n} / \mathrm{p}$ InP solar cells with excellent radiation resistance could be processed by a relatively simple closed tube diffusion process [refs. 5,6]. Progress in achieveing high efficiencies, dating from that time, is shown in figure 1. All data shown are air mass zero, total area measurements obtained at NASA Lewis. The highest AM0 efficiency shown (18.8\%) was obtained by a combination of 
OMCVD and ion-implantation [ref. 7]. Additional details regarding this highest efficiency cell can be found in reference 7 and in the paper by Keavney and Spitzer presented at this conference.

For reasons of economy, all of the cells shown in figure 1 are of small area $\left(0.25 \mathrm{~cm}^{2}\right)$. Recently, however, larger $\left(4 \mathrm{~cm}^{2}\right)$ cells have been produced using a closed tube diffusion process [refs. 8,9 ]. For these latter cells $\operatorname{In}_{2} \mathrm{~S}_{3}$ was used as a diffusion source to produce the sulphur doped n-region into a zinc doped p-type substrate doped to $2 \times 10^{16} / \mathrm{cm}^{3}$. These cells were produced on a production basis to yield $1 \mathrm{~cm} \times 2 \mathrm{~cm}$ cells in addition to the $4 \mathrm{~cm}^{2}$ cells (figure 2). A small sample of these cells was received and measured at NASA Lewis, the results being shown in table I. Also shown for comparison are measurements performed on the small area, highest efficiency cell of figure 1 . It is noted that the cells produced by OMCVD have much higher open circuit voltages than the cells produced by closed tube diffusion. This is believed to be due, mainly, to the absence of back surface field in the large area cells [ref. 8]. This deficiency is inherent in the methodology used to produce these cells, i.e. diffusion into a thick Czochralski grown InP wafer [ref. 8]. The larger area cells, which presently are of moderately high efficiencies, are intended for use on a small piggyback lunar orbiter, attached to the Muses-a spacecraft, to be launched in February, 1990. A cutaway view of the spacecraft is shown in figure 3 . The larger spacecraft will perform periodic lunar swingbys. At the first swingby, the small lunar orbiter will be injected into an orbit around the moon. Power for the lunar orbiter will be generated by approximately $10002 \mathrm{~cm}^{2}$ InP cells with 50 micrometer thick cover glass. The orbiter is spin-stabilized with the InP cells generating about 10 watts of power [ref. 10]. Since the moon lacks a measureable magnetic field, the lunar orbiter will not be subjected to a severe ambient radiation environment. In fact, radiation due to solar flares will present the severest radiation hazard to the small lunar orbiter. Thus, rather than being a severe test of the behavior of InP cells in a strong radiation environment, the forthcoming lunar orbiter will serve mainly as a vehicle for space qualification of these cells.

\section{Radiation Effects}

The results of $10 \mathrm{MeV}$ irradiations are shown in figure 4 where the $2 \mathrm{~cm}^{2}$ cells, typical of those to be used on the lunar orbiter, are compared to $n / p$ GaAs and small area, diffused junction, $n / p$ InP cells. Pre-irradiation parameters for these cells are shown in table II together with pre-irradiation parameters for ITO/InP cells to be discussed in a subsequent section of the present paper. It is seen from figure 4 , that the $2 \mathrm{~cm}^{2}$ InP cells outperform the smaller area InP cells at the lower fluences but fall off at the higher fluences. Both InP cells exhibit radiation resistance superior to the GaAs cell. With regard to the behavior at high fluence, it is noted that the larger area InP cell has a junction depth between 0.2 and 0.3 micrometers [ref. 8], while the junction depth for the small area cell is well under 0.1 micrometer ref. 11]. Dependence of radiation resistance on junction depth has been previously observed for GaAs where a decrease in junction depth was observed to accompany increased radiation resistance [ref. 12]. In the absence of similar data for InP, it is speculated that the fall off at higher fluences may be due to the cell's relatively large junction depth. On the other hand, the increased radiation resistance observed at lower fluence may possibly be due to better substrate quality in the larger area cells.

ITO/InP solar cells present a lower cost processing alternative to the more common $\mathrm{n} / \mathrm{p}$ homojunction cells. Previous experience with silicon solar cells, in which an oxide was an active cell component, led to the strong possibility that radiation induced degradation in the oxide was a significant factor in cell degradation [ref. 13]. Thus it is relevant to assess the peformance of ITO/InP cells in a radiation environment rather than taking it for granted that their radiation resistance will 
be similar to that observed for the $\mathrm{n} / \mathrm{p}$ homojunction cells. The results of such irradiations are shown in figure 5 while pre-irradiation cell parameters are listed in table II. The indicates that the present ITO/InP cells have radiaton resistance, under $10 \mathrm{MeV}$ proton irradiation, which is comparable to that of the $\mathrm{n} / \mathrm{p}$ homojunction cells [ref. 14]. The present ITO/InP cells, supplied by Dr. T. J. Coutts of the Solar Energy Research Institute, were processed by D. C. magnetron sputtering of ITO onto zinc doped p-type InP whose dopant concentration was $3 \times 10^{16} / \mathrm{cm}^{3}$. Examination of the ITO/InP interface by Raman spectroscopy and ellipsometry indicates that the cell configuration is most probably that of a semiconductor-insulator-semiconductor, the insulator being a-InP.

\section{Theory}

Comparisons of InP and GaAs cells, under laboratory irradiations, have employed cells with widely different pre-irradiation parameters. For example; the $\mathrm{n} / \mathrm{p}$ GaAs cell of figure 4 has a base dopant concentration which is an order of magnitude greater than that of the $n / p$ InP cells. Previous comparisons, under $1 \mathrm{MeV}$ electron irradiation, have used $\mathrm{p} / \mathrm{n}$ GaAs cells with an AlGaAs window for comparison with $\mathrm{n} / \mathrm{p}$ InP cells [ref. 1]. In this latter case, the base dopant concentration of the GaAs cell was again an order of magnitude greater than that of the InP cell. In addition, the geometry of the two cell types was markedly different. In order to compare these cells on an equal basis, a computer calculation was performed using a previously published computer model [refs. $4,16]$. The parameters chosen for comparing both $\mathrm{n} / \mathrm{p}$ cells are shown in table III. Using these parameters, an AM0 efficiency of $20.4 \%$ is predicted for InP while $21.5 \%$ is predicted for GaAs [ref. 16]. However, by reducing the emitter width to 250-300 Angstroms, front contact grid shadowing to $4 \%$ and by use of an optimized two layer AR coating, the optimum efficiency is $21.5 \%$ for InP and $22.5 \%$ for GaAs [ref. 16].

Because of carrier removal effects, it was necessary to use lifetime damage coefficients $K_{T}$ to compute the degradation. The plot used to abtain $\mathrm{K}_{\tau}$ for $\mathrm{InP}$ is shown in figure 6 , a similar plot being used for GaAs [ref. 16]. From these data it is found that $K_{r}=1.3 \times 10^{-6} \mathrm{~cm}^{2} / \mathrm{s}$ for InP while for GaAs $\mathrm{K}_{\tau}=3.1 \times 10^{-5} \mathrm{~cm}^{2} / \mathrm{s}$. The computed results for identical cell configurations and doping densities show that the calculated performance of $\operatorname{InP}$ is superior to that of GaAs under $1 \mathrm{MeV}$ electron irradiation (figure 7) [ref. 16]. It was also concluded that the superior radiation resistance in this case was not due to the higher absorption coefficient of InP, but was due to the intrinsic nature of the defects in these two cell types [ref. 16]. In this connection, Yamaguchi has tentatively concluded that "the radiation properties of the InP cells was attributable to room temperature and light enhanced annealing phenomena of the major defect centers in InP. The radiation resistance of In $\mathrm{P}$ was associated with the lower migration energy of indium and phosphorus displaced atoms in InP compared with those of the Ga or As displaced atoms in GaAs." [ref. 17]

\section{Conclusion}

Achievement of AMO efficiencies approaching $19 \%$ makes the ultimate goal (20\%) appear attainable. Although the present highest efficiency cells are relatively small, it should be recalled that, for GaAs, efficiencies over $18 \%$ were reported, in 1972, for cells whose area was considerably smaller than the present small area cells [ref. 18]. The latter cells are of adequate size for concentrator applications such as in the miniature cassegrainian concentrator [ref. 19]. However, much larger areas are required for planar arrays. The present larger area InP cells, with moderately high efficiencies, are 
a first step in this direction. However, as previously noted, the method used to produce these larger area cells apparently has inherent limitations. In addition to its flexibility, the use of an epitaxial growth method usually results in a cell base which has less defects than a base consisting solely of a Czochralski grown wafer. Thus it is anticipated that the highest efficiency large area InP cells would ultimately be produced by an epitaxial technique. Aside from this there remains the question of cost and the capability of producing large, useable quantities of these cells. The present substrate costs are high but should be reduced when the cells are produced in large quantities. However, a more attractive cost reduction alternative lies in the use of heteroepitaxial growth on cheaper, sturdier substrates. Another alternative for cost reduction lies in the use of techniques, such as the CLEFT process, in which the substrate is reuseable [ref. 20]. With respect to production in quantity, the example of the cells intended for the small lunar satellite indicates that, if a demand exists, cells of moderately high efficiencies can be produced in relatively large amounts. However, for quantity production of large area higher efficiency cells, epitaxial growth appears to be the method having the greater possibility of success.

\section{References}

[ 1] I. Weinberg, C. K. Swartz, R. E. Hart, Jr., and R. L. Statler, Proceedings 19 th IEEE Photovoltaic Specialists Conference, p. 548 (1987).

[ 2] M. Yamaguchi, Y. Itoh and K. Ando, Appl. Phys. Lett. 45, 1206 (1984).

[ 3] K. Ando and M. Yamaguchi, Appl. Phys. Lett. 47, 846 (1985).

[4] C. Goradia, J. Geier and I. Weinberg, Proceedings 19th IEEE Photovoltaic Specialists Conference, p. 937 (1987).

[5] M. Yamaguchi, C. Uemura, A. Yamamoto and A. Shibukawa, Japanese Journal of Applied Physics 23, 302 (1984).

[6] A. Yamamoto, M. Yamaguchi and C. Uemura, Appl. Phys. Lett. 44, 611 (1984).

[ 7] C. J. Keavney and M. B. Spitzer, Appl. Phys. Lett. 52, 1439 (1988).

[ 8] H. Okazaki, T. Takamoto, H. Takamura, T. Kamei, M. Ura, A. Yamamoto and M. Yamaguchi, Tech. Digest, Srd Int'l Photovoltaic Science and Engineering Conf., Tokyo, p. 791 (1987).

[ 9] I. Weinberg, C. K. Swartz, R. E. Hart, Jr., S. K. Ghandhi, J. M. Borrego, K. K. Parat and M. Yamaguchi, Solar Cells 22, 113 (1987).

[10] M. Nagatomo, Institute of Space and Astronautical Science, Tokyo, Private Communication.

(11] K. K. Parat, S. Bothra, J. M. Borrego and S. K. Ghandhi, Solid State Electronics 30, 283 (1987).

[12] R. Loo, G. S. Kamath and R. C. Knechtli, Proceedings 1 th th IEEE Photovoltaic Specialists Conference, p. 1090 (1980).

[ 13] I. Weinberg, H. W. Brandhorst, Jr., C. K. Swartz and V. G. Weizer, Proceedings 2nd European Symposium on Photovoltaic Generators in Space, p. 129 (1980).

[ 14] I. Weinberg, C. K. Swartz, R. E. Hart, Jr. and T. J. Coutts, to be published in Proceedings 20th IEEE Photovoltaic Specialists Conference, (1988).

[15] T. J. Coutts, Solar Energy Research Institute, Private Communication.

[16] C. Goradia, J. V. Geier and I. Weinberg, Tech. Digest, Srd Int'l Photovoltaic Science and Engineering Conf., Tokyo, p. 207 (1987).

[ 17] M. Yamaguchi, Tech. Digest, Srd Int'l Photovoltaic Science and Engineering Conf., Tokyo, p. 471 (1987).

[ 18] J. M. Woodall and H. J. Hovel, Appl. Phys. Lett. 21, 379 (1972).

[ 19]R. E. Patterson, H. S. Rauschenbach and M. D. Cannady, Proceedings 16th IEEE Photovoltaic Specialists Conference, p. 39 (1982).

[20] R. W. Mclelland, C. O. Bozler and J. C. C. Fan, Appl. Phys. Lett. 37, 560 (1980). 
TABLE 1. - AMO PARAMETERS-IMP SOLAR CELLS

\begin{tabular}{|c|c|c|c|c|c|c|}
\hline CE L L & & $\begin{array}{c}\text { NO } \\
\text { OF } \\
\text { CELLS }\end{array}$ & $\begin{array}{c}\mathrm{JsC} \\
\mathrm{MA} / \mathrm{Cn}^{2}\end{array}$ & Voc & $\begin{array}{l}\text { FF } \\
\text { PERCENTT }\end{array}$ & EFFICIENCY \\
\hline \multirow{2}{*}{$\begin{array}{l}\text { JAPAN } \\
2 \mathrm{CH}^{2}\end{array}$} & BEST & & 32.9 & 825 & 83 & 26.4 \\
\hline & AVERAGE & 6 & $31.6 \pm 1$ & $824: 1$ & $82.4 \pm 1$ & $15.6 \pm .6$ \\
\hline \multirow{2}{*}{$\begin{array}{l}J A P A N \\
4 \quad C H^{2}\end{array}$} & BEST & & 33.7 & 828 & 81.6 & 16.6 \\
\hline & AVERAGE & 5 & $33.5 \pm .2$ & $826 \pm 1$ & $81.5 t .5$ & $16.4 \varepsilon .1$ \\
\hline \multirow{2}{*}{$\begin{array}{l}\text { U.S.A. } \\
0.25 \mathrm{CH}^{2}\end{array}$} & BEST & & 35.7 & 873 & 82.9 & 28.8 \\
\hline & AVERAGE & 8 & $35.7 \star .2$ & $868 \cdot 6$ & $80.8+2$ & $18.21 .5^{\circ}$ \\
\hline
\end{tabular}

TABLE II. PREIRRADIATION AMO PARAMETERS OF CELLS IN FIGS. 485

\begin{tabular}{|c|c|c|c|c|c|}
\hline CELH & $\begin{array}{l}\text { AREA } \\
\mathrm{CH}^{2}\end{array}$ & $\frac{\text { EEEICIENCY }}{x}$ & $\frac{\mathrm{dSS}}{\mathrm{MA} / \mathrm{cm}^{2}}$ & $\frac{\text { LE }}{\text { nV }}$ & EE \\
\hline W/ IMP & 2 & 16.4 & 32.9 & 825 & 83 \\
\hline W/P IUP & 0.25 & 13.6 & 27.6 & 826 & 81.8 \\
\hline W/P GaAs & 4 & 16.6 & 29 & 960 & 81,8 \\
\hline ITO/IMP & 0.72 & 13.2 & 32.6 & 761 & 78 \\
\hline
\end{tabular}


TABLE III. - PREIRRADIATION CELL PARAMETERS USED IN THEORETICAL COMPARISON OF InP AND GaAs

\begin{tabular}{|c|c|c|}
\hline & $\operatorname{In} P$ & GaAs \\
\hline $\begin{array}{l}\text { Junction Area, } \mathrm{cm}^{2} \\
\text { Total Illuminated Area, } \mathrm{cm}^{2} \\
\text { Grid Coverage, } \mathrm{Z} \\
\text { Specific Contact Resistance, ohm- } \mathrm{cm}^{2} \\
\text { Front SRV, cm/sec } \\
N^{+} \text {Emitter Width, angstroms } \\
\mathrm{N}^{+} \text {Emitter Doping, cm-3 } \\
\text { P Base Width, micrometers } \\
\text { P Base Doping, cm-3 } \\
\text { P BSF/Buffer Width, micrometers } \\
\text { P }^{+} \text {BSF/Buffer Doping, cm-3 }\end{array}$ & $\begin{array}{l}1.00 \\
0.94 \\
6.00 \\
1.0 \mathrm{E}-3 \\
1.0 \mathrm{E} 5 \\
400 \\
6.0 \mathrm{E} 17 \\
1.50 \\
5.0 \mathrm{E} 16 \\
250 \\
5.0 \mathrm{E} 18\end{array}$ & $\begin{array}{l}1.00 \\
0.94 \\
6.00 \\
1.0 \mathrm{E}-3 \\
3.0 \mathrm{E} 5 \\
400 \\
6.0 \mathrm{E} 17 \\
1.0 \\
5.0 \mathrm{E} 16 \\
250 \\
5.0 \mathrm{E} 18\end{array}$ \\
\hline
\end{tabular}

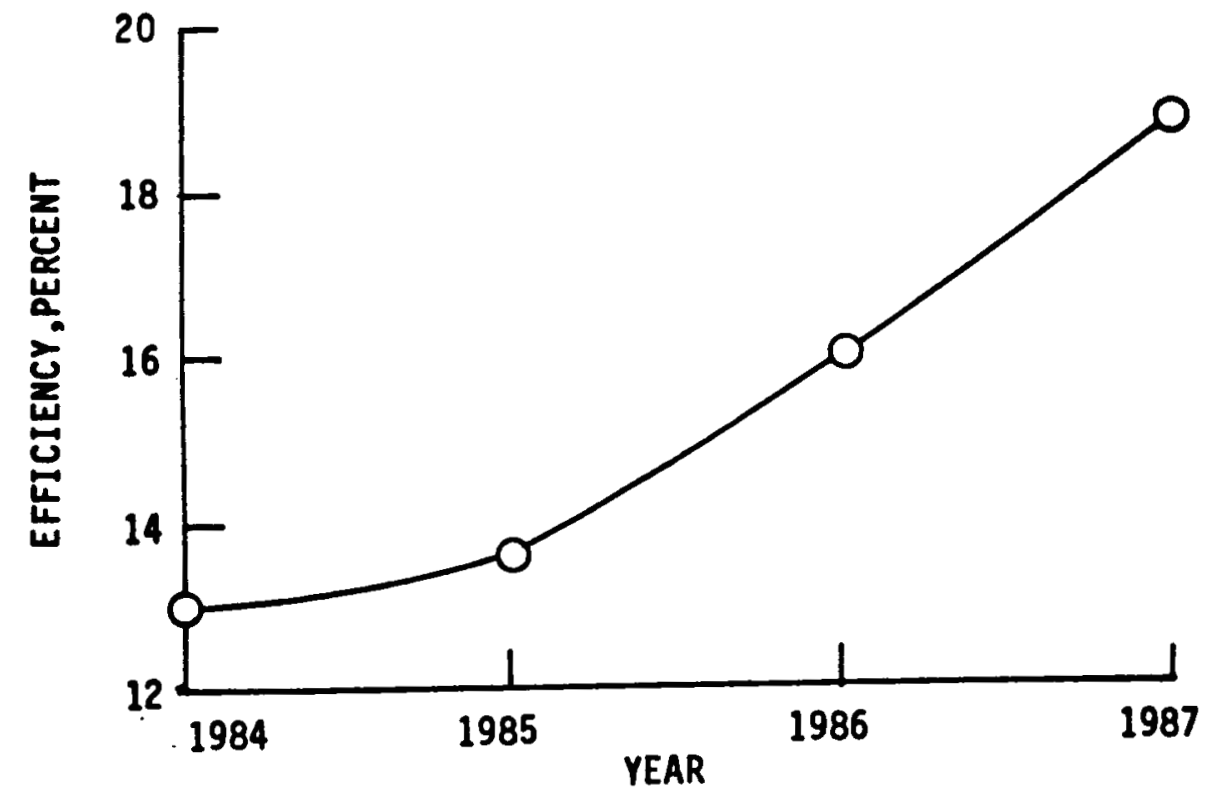

FIGURE 1. - PROGRESS IN ACHIEVING HIGH EFFICIENCY InP SOLAR CELLS. 


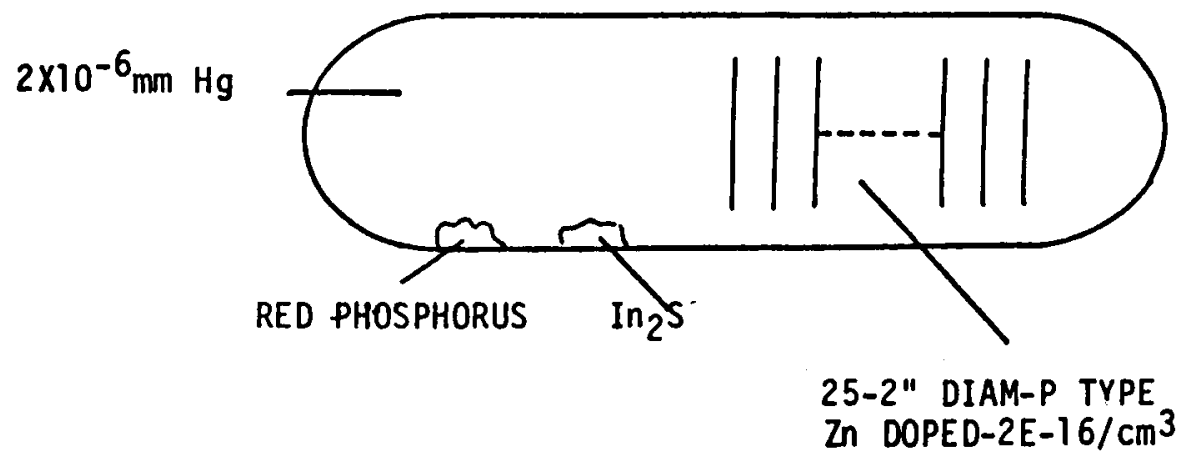

AMO-TOTAL AREA PERFORMANCE PARAMETERS

$\begin{array}{ccccc}\frac{A R E A}{\mathrm{~cm} m^{2}} & \frac{\mathrm{JSC}}{\mathrm{mA} / \mathrm{cm}^{2}} & \frac{V O C}{\mathrm{mV}} & \frac{F F}{\%} & \frac{E F F}{\%} \\ 4 & 33.8 & 821 & 83 & 16.7\end{array}$

H. OKAZAKI, ET. AL. PVSEC 3, PG. 793, TOKYO, NOV.1987

FIGURE 2. PRODUCTION OF LARGE AREA InP CELLS

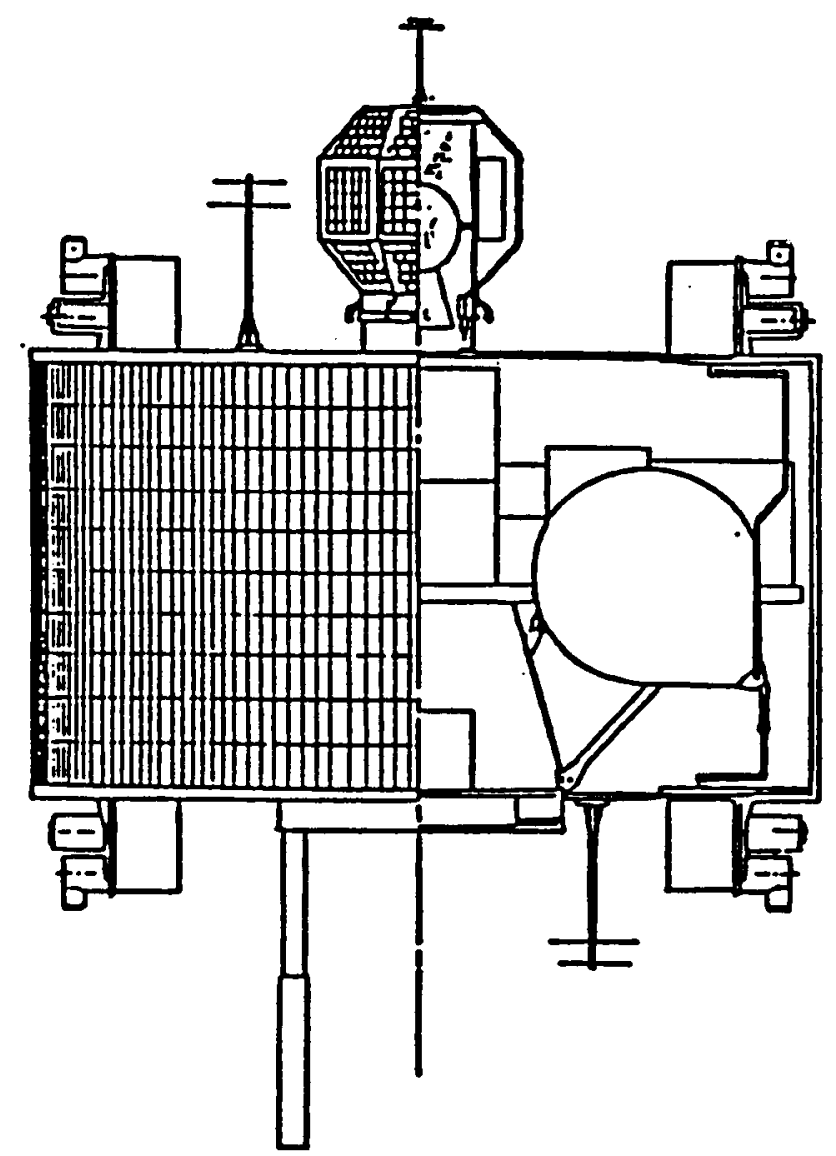

FIGURE 3 MUSES-A SPACECRAFT 


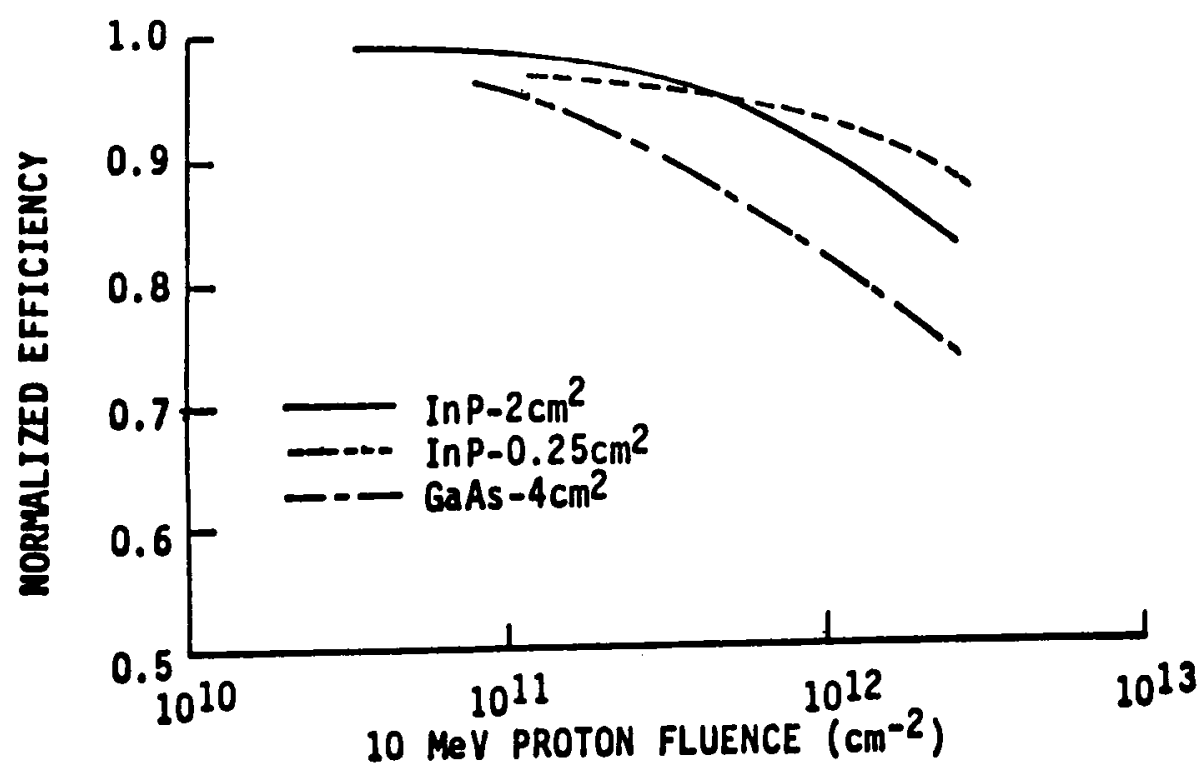

FIGURE 4. - NORMALIZED EFFICIENCIES UNDER $10 \mathrm{MeV}$ PROTON IRRADIATION-INP AND GaAS.

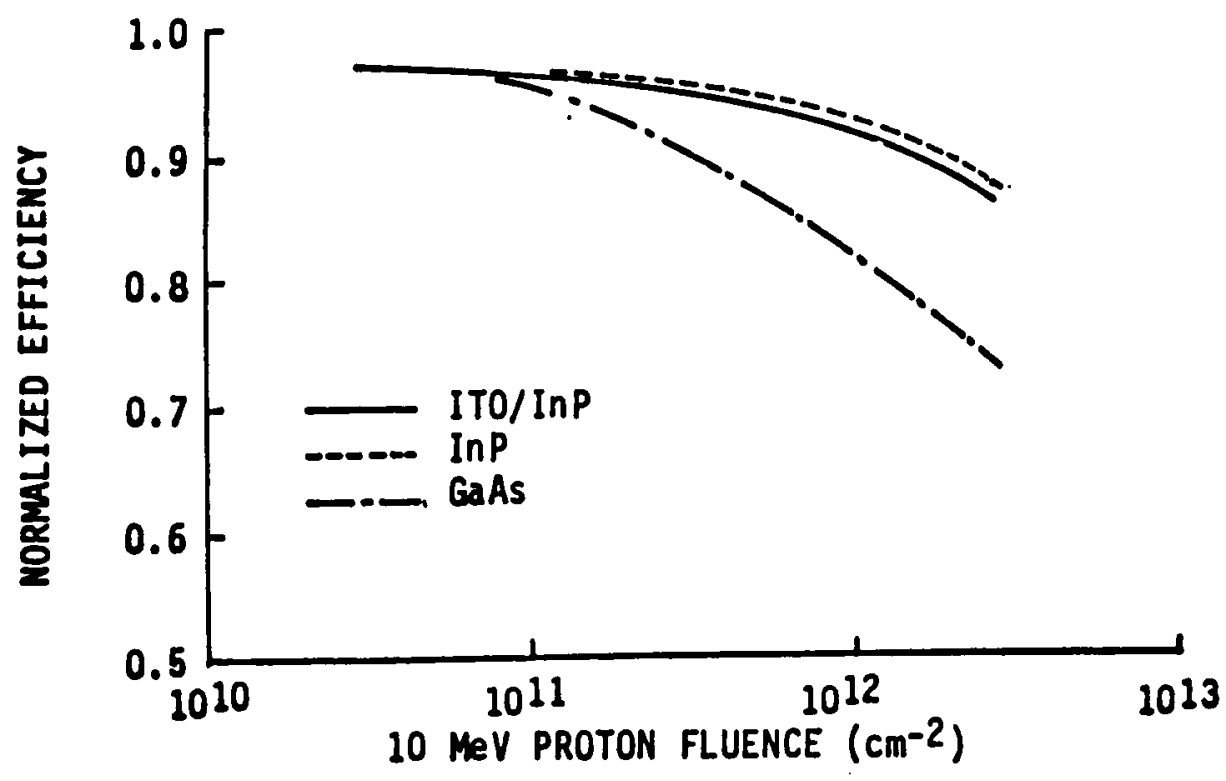

FIGURE 5. - NORMALIZED EFFICIENCIES UNDER $10 \mathrm{MeV}$ PROTON IRRADIATION-ITO/INP, InP and GaAs. 


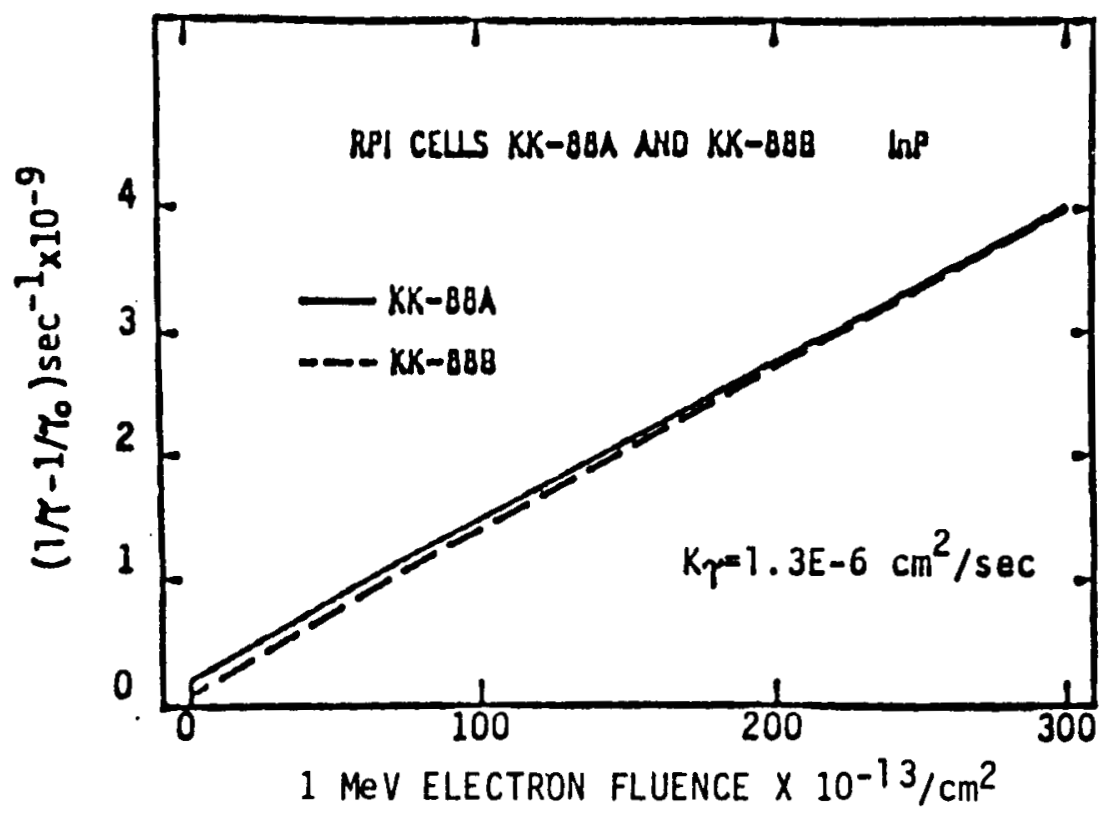

FIGURE 6. - GRAPHICAL PLOTS USED TO OBTAIN LIFETIME DAMAGE COEFFICIENTS OF InP.

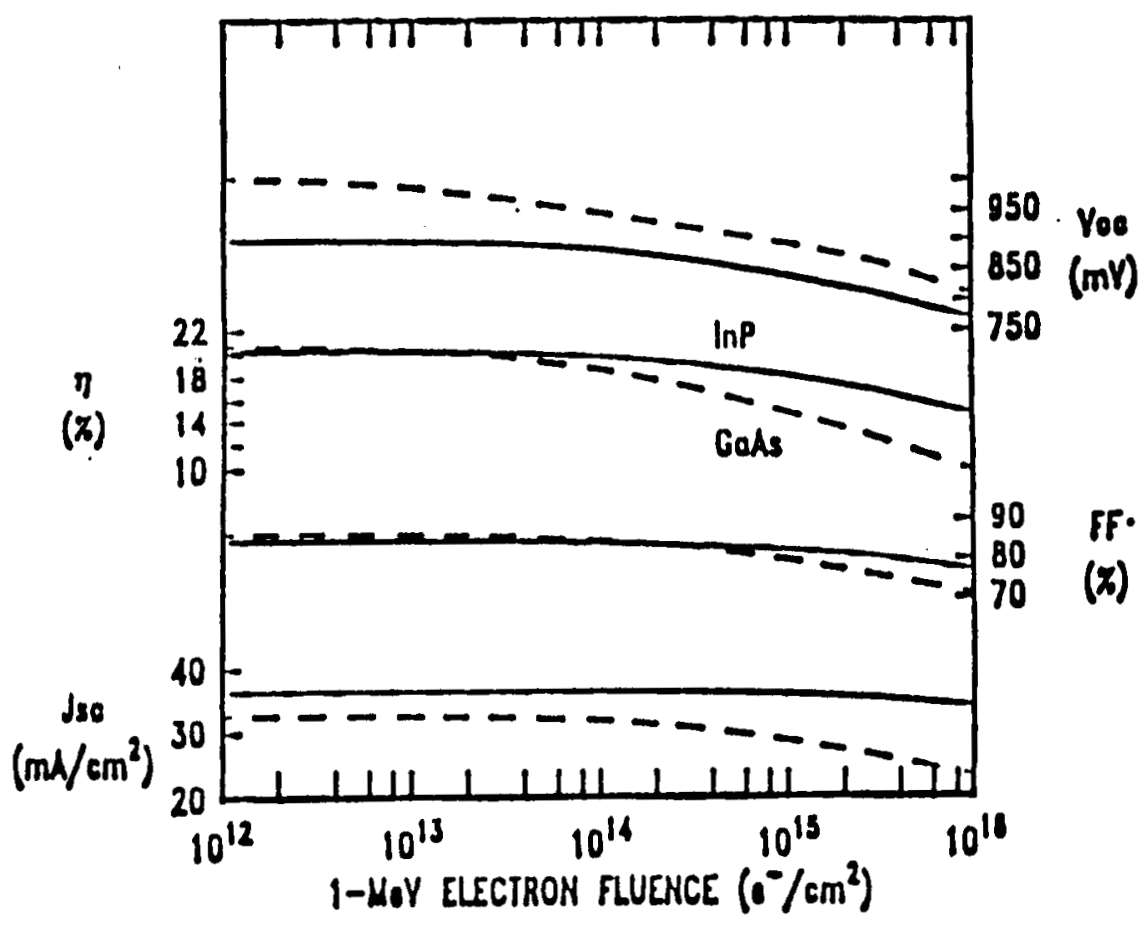

FIGURE 7. - CALCULATED PERFORMANCE OF InP AND GaAS UNDER I MEV ELECTRON IRRADIATION. 